\title{
The theoretical basis of the digital economy in the strategic planning documents
}

\author{
Oleg Dyachenko, ${ }^{1, *}$ \\ ${ }^{1}$ The Chelyabinsk State University, Department of Economics of Industries and Markets, \\ Chelyabinsk, Russia
}

\begin{abstract}
The article analyzes the definitions of the concept "digital economy". The study considers the strategic planning documents of the different states, dedicated to the project of digital economy, as the object of investigation. The subject of research is the interpretation of the category "digital economy". The theoretical and methodological issues in the study of the digital economy are considered. The paper makes an attempt to substantiate the problems that will follow in the implementation of the strategy under the conditions of a weak methodological basis for describing the existing techno-economic picture of the world. Among such problems, we emphasize the lack of attention to the production relations in the presented interpretations. We consider that building a digital economy, as a high-tech production ecosystem, will not do without understanding the essence of a new type of production relations. Without this understanding, it will be problematic to build the institutional basis of the digital economy and to create a regulatory framework to control emerging relationships in the digital economy. The paper critically analyzes the existing interpretations of the digital economy, presented in the strategic planning documents, and reveals the author's understanding of the studied category.
\end{abstract}

\section{Introduction}

The digital economy is a unique project, which previously had only rudimentary local manifestations, both in the world practice and in Russia. At the present time, a special attention is paidat the state level to the issue of building an information society and to the process of digitalization. However, the state programs of formation of the digital economy in different countries have a far-reaching and ambiguous perspective. Uncertainty in the construction of the digital economy is determined by a system of factors, including the following ones: the absence of tools for describing and understanding current changes in the modern economy, the unfounded judgments about the prospects of the digital economy, and unreasoned government strategies in the sphere of digitalization and state support for this process among the priorities of national development. A number of conceptual and important theoretical issues concerning the essence of the phenomenon, its historical place, the nature of industrial relations and some others remained unresolved.

\footnotetext{
*Corresponding author: dyachenko@csu.ru
} 


\section{Degree of scientific elaboration}

The idea of digitalization in the scientific sphere is not new in international economic practice. Among the scientists who are actively engaged in the study of digitalization, the processes of informational support we distinguish both classics of scientific thought, whose ideas formed the conceptual core of the work, which were shifted from futuristic utopian theoretical developmentsinto the research thought in the field of science, and mainstream researchers.

Among the scientists, who can be described as "the builders of the foundation of the information economy (information society) theory" we mark M. McLuhan [1], Y. Masuda [2], F. Machlup [3], M. Porat [4], J. Naisbitt [5], V. Mosco [6], D. Lyon [7], W. P. Dizard [8], T. Stonier [9], M. Castells [10], B. Gates [11] and others.

The results of scientific studies of modern researchers are of particular interest.We pay attention to the works of the following authors: N. Negroponte[12], D. Tapscott [13], K. Kelly [14], D. Schiller [15], J. W. Cortada [16], J. Christensen [17], H. Kehal [18], B. Johanson [19], G. Illing [20], P. Welfens [21], E. Brousseau [22], E. J. Malecki[23], R. H. Weber [24], E. Schmidt [25], U. Huws [26], C. Holroyd [27], F. BocciaandR. Leonardi [28], D. Elder-Vass [29] and others.

Analyzing the accumulated theoretical and methodological basis of the digital economy theory, we highlight the following main areas of its research objects.

First, a huge number of scientists are occupied with studying the impact of modern digital technologies on various spheres of human life, primarily the impact on the economic sphere. They study prospects of implementation of various critical, through innovative technologies and their impact on business, aconsumer behavior, a market behavior and many other things.

Secondly, the attention of researchers is drawn to the problem of transformation of existing "traditional" institutions in connection with the penetration of a new technological structure into the economic practice.

Thirdly, the study of the contradictions between modern productive forces and getting out of date productive relations.

Fourth, thanks to modern developments in the field of socio-economic forecasting and modeling, researchers regularly raise questions about the future of the world order. From the perspective of the digital technologies progress, scientists make attempts to describe the prospects, concerning the place that people will occupy in the sphere of production, the role of the state, the global problems of the mankind and many other things.

Fifth, investigations are conducted in the sphere of describing the technical nature of the digital economy: its infrastructure, technological support for the construction of the digital platforms, the digital state, etc.

The theory of the information society, which has evolved into the theory of digital economy is not new. Various scientists with different political and economic views have been developing this theory since the middle of the 20th century. It should be noted that to the 90 -th years of the 20th century the attention to this theory started to fade because of the increased criticism and the emergence of more progressive ideas, claiming to be a more accurate description of the current economic picture of the world and having a better

forecasting and recommendatory instrumentarium. Nevertheless, the current stage of the economic development demonstrates a deeper and fundamental involvement of the digital technologies in the economic processes, comparing with the beginning of the 21 st century. On this basis, the scientific community cannot ignore the fact that the digital revolution is approaching. Throughout the history of humanity, there were technologies the influence of which carried risks to the established traditions, norms, rules and life. A wheel, a textile machine, a steam engine and then an electric engine and internal combustion engine, 
microelectronics, information technology as innovations leveled inefficient forms of social relations, which means, according to J. Schumpeter carried out "creative destruction."Regardless of the existing criticism of the techno-deterministic nature of the digital revolution, we can note the objective nature of the changes taking place in many countries, including 3 countries of the world. Based on this, the relevance of the study of the nature of the digital economy, its forms of manifestation, its impact on the traditional sectors of the economy and some other things will increase in the future. Based on this, we believe that the return of the theory of information (digital, network, virtual, etc.) economy in the mainstream of scientific discussions will not be long in coming.

\section{Strategic planning in the digital economy}

Today, we see that the ideas worked out several decades ago are beginning to find their embodiment in the implementation of state economic policy in the most developed countries. These conceptual developments overcome the format of ideas and begin to be implemented in the state strategic documents.

At the present time, government programs and strategies for the development and promotion of digital technologies and digitalization of economies are implemented in dozens of countries. According to the official data of the European Commission, there are more than 30 national and regional initiatives regarding the digitalization of the industrial sector in the countries of the European Union.

Table 1. Documents of strategic planning in the sphere of digital economy in different countries.

\begin{tabular}{|l|c|}
\hline Country & \multicolumn{1}{c|}{ Title of the document } \\
\hline China & $\begin{array}{c}\text { "Made in China-2025" [30], "Internet Plus" [31], "Next } \\
\text { Generation Artificial Intelligence Development Plan" [32]. }\end{array}$ \\
\hline Germany & "Digital strategy 2025"[33], "Industry 4.0"[34] \\
\hline France & "Building France's industrial future" [35] \\
\hline Great Britain & $\begin{array}{l}\text { "UK Digital Strategy" [36], "Strategy for the Infor- } \\
\text { mation Economy"[37] }\end{array}$ \\
\hline Australia & "The National Digital Economy Strategy"[38] \\
\hline Austria & "Industry 4.0 Austria"[39] \\
\hline Russia & "Digital Economy" Program Implementation[40] \\
\hline Japan & "Smart Japan ICT Strategy"[41] \\
\hline EU & "Digital single market"[42] \\
\hline Sweden & "Smart industry"[43] \\
\hline The Netherlands & "The Netherlands: Smart industry"[44] \\
\hline
\end{tabular}

In addition, we consider that scientific investigations and developments in the digital economy will become more relevant in the next few years, as the risk of falling behind the global trends of digital transformation is constantly increasing. It is this fact that explains why the developed countries initiated programs for the development of the digital economy at about the same time interval.

The success of the implementation of the state economic policy is largely determined by the accuracy of the strategic planning system. The quality of elaboration of the strategic document at the state level is ensured by the level of knowledge of several interrelated and necessary elements. Firstly, it is the accumulated conceptual basis, theoretical and methodological platform for the study of the object; secondly, an adequate and a really close to reality description of the existing situation in the economic practice, on the basis of 
the first item; thirdly, the developed system of management decisions and recommendations on the basis of the first and the second items.

We should not provide evidence that the goals set in the strategies for the implementation of the digital economy will not be achieved if the science does not substantiate, how it will be done, and who will benefit from it.

\section{Methodological instrumentarium of the problem investigation}

A number of conceptual approaches to the interpretation of the category "digital economy" are based on scientific ideas developed within the framework of the information society theory. About the approaches in detail:

First, it is the sector of economy where digital technologies and related components are produced;

Secondly, this category is understood as a set of relationships that develop between different stakeholders on the electronic platforms by means of the Internet;

Third, the digital economy is understood as a set of electronic business processes occurring in the organizational structures at various levels (from the household-level production to the state level);

Fourth, these are markets based on digital technologies;

Fifth, it is a general scientific definition of the existing economic development stage;

Sixth, it is the "name of the project" implemented by the governments of different countries.

Due to the fact that there is no coherent theory of the digital economy, these approaches have the right to exist. On the one hand, the listed approaches can be presented as objects of the research, as they reveal the whole essence of the digital economy. On the other hand, these approaches are only categorical structural elements of the digital economy, which do not reveal the essence of the phenomenon; they are presented as subjects of the research of the new "coming" economy model. If these approaches are presented as subjects of the scientific research, they are characterized by various theoretical and methodological tools to learn the phenomenon. These tools of knowledge (an institutional approach, Economics, a political economy approach, etc.) consider the subject of the study and give different answers to the questions (what to produce, how to produce, for whom to produce).Studying the digital economy (the subjects of research) through various "methodological prisms", you will see the nature, the mechanisms and the patterns of existence and development of the subject of observation. Besides, the science will give answers and recommendations on the problems in this field of knowledge. Logically all the recommendations should be different. Thus, in many strategic planning documents of various states, it is banked on the digital economy to ensure the competitiveness of the national economy in the international market, improve the quality of life of the population, form a strong and stable government, ensure state security, etc. Accordingly, we consider that it is impossible to substantiate the achievement of common (for many states) strategic development goals with different "starting" theoretical interpretations and theoretical and methodological approaches with their vision of the principles of development.

The variation of scientific approaches and disclosure of the key categories in strategic documents is usually significant. Nevertheless, the public significance of what is written in this type of document is much higher than the concentrated scientific knowledge reflected in scientific studies. Accordingly, as an object of analysis, we consider the vision of the category of "digital economy", presented in the state strategic documents, as well as in various publications of public authorities. The main task is to describe the general conceptual vision of the digital economy by different governments. 
Table 2. Interpretation of the category "Digital economy" in the strategic documents.

\begin{tabular}{|c|c|}
\hline Country & Categories content \\
\hline OUP 2017 & $\begin{array}{l}\text { "An economy which functions primarily by means of dig- } \\
\text { ital technology, especially electronic transactions made using } \\
\text { the Internet". [45] }\end{array}$ \\
\hline $\begin{array}{l}\text { G20 Digital Economy De- } \\
\text { velopment and Cooperation } \\
\text { Initiative }\end{array}$ & $\begin{array}{l}\text { This is a broad range of economic activities that include } \\
\text { using digitized information and knowledge as the key factor } \\
\text { of production, modern information networks as an important } \\
\text { activity space, and the effective use of information and } \\
\text { communication technology (ICT) as an important driver of } \\
\text { productivity growth and economic structural optimization } \\
\text { [46] }\end{array}$ \\
\hline $\begin{array}{l}\text { European Commission, } \\
2013\end{array}$ & $\begin{array}{l}\text { "...an economy based on digital technologies (sometimes } \\
\text { called the internet economy)". [47] }\end{array}$ \\
\hline OECD, 2016 & $\begin{array}{l}\text { "The digital economy enables and executes the trade of } \\
\text { goods and services through electronic commerce on the } \\
\text { Internet" [48] }\end{array}$ \\
\hline $\begin{array}{l}\text { Department of Broadband } \\
\text { Communications and the } \\
\text { Digital Economy (DBCDE), } \\
\text { Australia } 2013\end{array}$ & $\begin{array}{l}\text { "The global network of economic and social activities that } \\
\text { are enabled by digital technology, such as the internet and } \\
\text { mobile networks". [49] }\end{array}$ \\
\hline $\begin{array}{l}\text { United States Census Bu- } \\
\text { reau }\end{array}$ & $\begin{array}{l}\text { Defined the digital economy as "having three primary } \\
\text { components": } \\
\text { - "E-business infrastructure is the share of total economic } \\
\text { infrastructure used to support electronic business processes } \\
\text { and conduct electronic commerce" } \\
\text { - "Electronic business (e-business) is any process that a } \\
\text { business organization conducts over computer-mediated } \\
\text { networks" } \\
\text { - "Electronic commerce (e-commerce) is the value of } \\
\text { goods and services soldover computer-mediated networks". } \\
\text { [50] }\end{array}$ \\
\hline Russia's government & $\begin{array}{l}\text { Economic activity in which data in digital form is a key } \\
\text { factor of production. Processing of large amounts of data and } \\
\text { the use of the analysis results of which, in comparison with } \\
\text { traditional forms of management, can significantly improve } \\
\text { the efficiency of various types of production, technologies, } \\
\text { equipment, storage, sale, delivery of goods and services [51] }\end{array}$ \\
\hline
\end{tabular}

Accordingly, from the presented definitions it can be noted that the existing economy is identified with the basic technology of modern technological structure. In our opinion, this approach is quite controversial. First, the fact that it is a source of progressive economic growth has not been proven. Anthropocentric concepts of economic development identify the human factor and the investment in human capital as the main growth drivers. Technocentric concepts in the center of economic growth distinguish modern digital technologies. The authors of government strategies approach to the definition of the category as a systemic phenomenon and imply that the digital technologies will ensure productivity, growth and development of the entire economic system. Considering the presented interpretations it can be noted that all of them have a technocratic basis. The role of an individual and a society that provides the demand for the work product of an individual is minimized. Secondly, the attempts to link the essence of the modern economy with a key resource do not look quite convincing. The 20th century is characterized by a systemic spread of electrification, a high role of hydrocarbons, nuclear energy and etc. Almost all attempts to introduce such concepts as hydrocarbon economy, bioeconomics, 
green economy and many other things in the field of economic science were unsuccessful and subjected to violent criticism. On the one hand, the object of state attention becomes clear, namely the attention of the regulators to a specific industry (the production of information and communication technologies, the education system, etc.).On the other hand, the implementation of industrial policy on the type of allocation of leading corporations and industries can cause a number of contradictions in the liberal market model of economies, as well as a number of imbalances in the economy. Third, in a number of government development strategies, the digital economy is revealed through the prism of trade. This approach is scientifically appropriate, but strategically false. Leadership in the 21 stcentury in the international arena will be assigned to those economies that will be able to provide competitive products with high added value to the market, provide the population with high-efficient jobs and high standards of life quality. We concider that the point of view, which is based on the idea of economic growth due to the emergence of opportunities in the field of trade to sell products using the Internet technologies, the development of financial innovations based on digital platforms, is unreasonable. On the one hand, it is a vision of a specific government action plan in a particular way. Interpretation of the nature of the digital economy through the prism of trade is the position of the existing government. Raising public finance by means of recycling sphere can solve tactical problems in the economy, increase the income of the most affluent segments of the population. On the other hand, inconsistency in the understanding of the economy by the international scientific and political digital community can cause inconsistency in the implementation of the strategy in each state. The project of digitalization can be compared with the project of implementation of international quality management standards. Inconsistency of issues in this area leads to the problems of product promotion on the international market. The digital economy project, from the perspective of the global economy, is based on the principle of network interaction. The more participants are in the market, the higher is the effect of the interaction, expressed in terms of growth. Misalignment at the initial stage of understanding of this project will lead to a decrease in the projected results specified in the strategic development programs. Thus, from the position of economic security of the state, this approach to the disclosure of the digital economy seems irrational.

Based on the above, an attempt will be made to give the author's definition of the concept of "digital economy", which does not claim to be true, but provides a basis for deeper reflection and a detailed consideration of this category.

Uncertainty in the description of the digital economy is determined by a system of factors, including the eclectic basis of tools to describe and understand the changes in the modern economy. On this weak methodological basis, judgments about the prospects of the digital economy are built, strategic guidelines, directions of state support are outlined, the place of digital economy programs among the priorities of economic development is determined.

Developing a definition for the category of "digital economy", we consider that it is not the main characteristic of the modern economy and its trends. There are hundreds of definitions of the current stage of economic development, which claim to be "the most accurate". The category "digital economy" is one of them. Thus, developing a definition for the phenomenon under study, we adhered to the following criteria. The developed concept in the semantic load should be evolutionarily superior to those concepts that were proposed much earlier by the theorists of the information society. The economy and the relations developing in it have radically transformed to the present day, and therefore many theoretical postulates of this concept have been refuted or become irrelevant. Today, ICT technologies have turned from a tool of information processing and transmission into an independent tool of value creation. New business models are emerging at both the micro 
and macro levels. Accordingly, the understanding of the information economy that existed fifty years ago should be different from the information (digital) economy that exists at the moment. Correspondingly, we consider that in connection with the turbulent changes in the digital high-tech sphere, in a few years, the interpretation of the category of "digital economy" as a basic element of strategic planning should also be edited.

Thus, we define the digital economy as a system of economic relations between economic entities, the state, as well as objects that are able to generate, accumulate, process and exchange information through ICT by means of the network.

A new feature in modern conditions is that people in the digital age moves away from the production process even further."Internet of Things" is spreading, "Industrie 4.0" project is being implemented, and finally, the development and implementation of artificial intelligence in economic processes in many countries of the world are being actively carried out. Technologies have reached the level of development when they produce their own product - information that has cost characteristics. By object we mean industrial infrastructure: buildings, structures, networks, mechanisms, machines, equipment and other things connected with the modern digital technologies on a network basis and participating in the production process. Industrial facilities are able to accumulate and exchange information with the other facilities included in the industrial infrastructure."Big data" technologies allow using the latest algorithms to process a large amount of information, giving owners the opportunity to make more accurate strategic management decisions on business development, making it possible for the state to conduct a more balanced and reasoned point policy.

\section{The main conceptual problems of the digital economy}

1. The conceptual definition of the place of "Information (digital) revolution" in the structure of industrial revolutions remains a topical issue. On the one hand, we can assume that the current stage of digitalization is a continuation of the third technological revolution, the origins of which date back to the 60 s of the 20thcentury.On the other hand, the current stage of economic development, characterized by the widespread introduction of digital technologies, can be described as the 4thtechnological revolution, about its fundamental nature and the depth of transformational shocks can be heard at various scientific events and read in advanced research publications. So, if we proceed from the 2 nd assumption, there are the following reflections.

A common point of view with regard to the penetration of innovation in economic practice, is that there is a reduction in the time passed from the stage of development of an innovative product to the stage of market penetration. Therefore, IT and Internet technologies entered first into the military sphere, then into the market in the 80-ies of the 20th century. During this period, the idea of forming an information society, which is actively trying to discern the mechanism of overcoming the negative consequences of the capitalist mode of management, is actively developing .

Certainly, scientific research and the prognostic potential of the developed theories allowed us to trace the impact of ICT on social relations and what these relations will be in the future. The vision of the digital future is limited by the forecasting horizon. However, over the past half-century, the society has not observed fundamental transformation changes. Of course, there are relative changes in employment, inequality, productivity, capital concentration, quality of life, etc., but these indicators are not characterized by explosive dynamics due to the improvement of digital technologies. There are some scientific studies that provide the basis for hypotheses that there is a close correlation between indicators of informatization and macroeconomic indicators, indicators of socioeconomic development, production indicators, but the study of such dependencies does not 
go beyond the scope of individual studies, and the results are not embodied in the new economic laws.

Is it possible to compare the process of digitalization with the changes in the introduction of the steam engine and electricity? Time of appearance of the steam engine and changes in a way of conducting economy was shorter, than at the modern results of the scientific and technical works put into circulation. In this case, can we talk about the revolution that has taken place, when we started to actively write scientific papers, publish strategic planning documents on the process of "digitalization" and "digital economy" only in the last 3-4 years?

The strategic planning documents of many countries identify the most advanced (crosscutting, critical, promising) technologies of the digital economy, which, according to forecasts, will forever change the face of the modern socio-economic structure of society, institutions and industrial base. Development and testing of technologies takes place everywhere in different countries' leading corporations. New business models are emerging due to the spread of technologies. A new vector of investment flows and capital concentration is outlined. A pool of champions of the new economy is being formed. In connection with these trends, the state, represented by public authorities, orients and adjusts the state economic policy to the new development priorities.

Thus, in many strategic programs devoted to the tasks of digitalization (EU, USA, UK, Japan, China), the planning period of the program implementation is set in 2030-2035. Based on the above, the uncertainty is as follows: if the fourth technological revolution is already unfolding, it will reach its peak in 15 years, or this is the period when favorable conditions will be created for the deployment of the effects of digitalization.

Modern economic science does not cope with the timely update of theoretical and methodological descriptive, prognostic and advisory tools, does not keep up with the knowledge of the trends that occur at the present historical stage. Based on that we are faced with the fragmented information about what economic era we are in, about the current trends and trends about the global vector of economic development. The depth of knowledge of the phenomenon nature determines understanding the relevance and importance of economic processes. Thus, if the theoretical and methodological basis of economic science is able to distinguish between the phenomena that post-Industrialists began to write about in the 1960s and the modern phenomena of digitalization of the economy, it is likely that the effectiveness of building a digital economy with the help of strategic planning tools will be much higher. Otherwise, there are many reasons to doubt the relevance of the digital economy ideas and the prospects of government projects in this area. If we scientifically substantiate the idea that the modern digital revolution is those economic changes that are formed only in recent years, the transformational effect of which will be only in a few decades, the question of the prospective distribution of scarce budget resources in the digital development program will be in doubt.

2) For the present, most of the works devoted to the prospects of the digital economy, raise questions about the impact of IT-technologies on the existing experience of management. Based on the description of the best practices of business structures, high-tech companies that acted as a testing ground for the introduction of new digital models of business issues, modern analysts predict how this or that industry will change after the introduction of digital technology, considering the risks and prospects for further market behavior on the innovations that have appeared.

As it was shown above, we consider that the accuracy of the forecast is determined by what theoretical and methodological approach was laid down in the study of the phenomenon. Thus, the Russian experience of studying the nature of various economic phenomena is largely based on the methodology of political science today. We consider that the tools of political economy are able to outline the boundaries of this phenomenon, 
describe at the necessary and sufficient level the nature, reveal the contradictions and find methods of their resolution in the construction of the digital economy.

For example, the economic course of Russia is taken to restore industry on a new hightech basis. In this regard, the relevance of the study of industrial relations, the prospects of their evolution for economic science is seen as extremely important. Moreover, for the recommendations in the field of industrial policy implementation, this knowledge becomes very relevant.

In the documents of various countries strategic planning the problem of development of legislative support of relations in the field of digital economy is raised. Since in the European practice of strategic planning a greater emphasis is placed on the consideration of the digital economy as a sphere of trade, the recommendations for the state economic policy will be focused on the support, legal security of the sphere of monetary transactions in the digital ecosystem. In this case, if the western economies have some claim to the formation of a digital ecosystem that will provide favorable conditions for the emergence of competitive high-tech products with high added value, it is impossible to do without a thorough study of the issue of industrial relations. Due to the lack of knowledge of the issue of industrial relations, the legal aspect of interaction between the participants of industrial relations will remain unprocessed.

The idea is developed that the digital economy will be realized when all the participants of economic relations will be introduced into the ecosystem and will be directly or indirectly involved in the creation of a product with a high content of information (knowledge/ideas) or a digital good. Without a network effect, a talk about the digital economy and the information society has many chances to remain only in the strategic documents and reports on the expenditure of state budget funds for digitalization projects. Based on this, the lack of development of legal relations can have a negative effect on the desire of subjects to enter into risky non-institutionalized industrial relations.

For example, in a number of strategic documents of Japan, the issue of technological diplomacy, the expansion of information technology agreements is put on the agenda. Based on the above, the lack of research in the field of industrial relations in the specific conditions of the digital economy within national borders, unresolved legal aspects of these relations will act as an obstacle to the formation of networks at the international level. A well-functioning ecosystem within the country is a necessary requirement of information security, it is a factor of economic growth. However, the lack of international digital ecosystems significantly reduce the possibilities and the potential of the national digital economies development. The lack of an international digital ecosystem can manifest itself in various forms - the lack of unified institutions for the development of digital economies, various technological infrastructure elements and the possibility of their reproduction, different theoretical and methodological representation of the essence of the digital economy, as well as ideas about its strategic importance at the present stage.

\section{Conclusion}

At present, Russian science has only to realize the nature of this phenomenon, to describe the diversity of the palette of manifestations of the digital economy. The program developed by the government is only a technical description of the goals, objectives, directions that will be carried out under the close attention and protection of the state.

Unknown, due to poorly developed scientific prognostic tools, is the part of economic phenomena that will appear "from below" as a response to the policy pursued by the state. A possible prospect is how private capital will adapt to the new turbulent technical and economic conditions and shape its vision of the digital economy. 
Any innovation is the destruction of the old, familiar, routine, everyday life. The digital economy project is not a separate innovation in the industry, but on the contrary, a huge transformation of the productive forces of society and the transition of industrial relations to a new qualitative level. Of course, due to the presence of the ideologists, the prevalence of some scientific schools over others, the domination of the liberal market paradigm, one can ignore the transformation of production, ignore the re-industrialization trends in the world. Nevertheless, the sphere of production is transforming and developing. The forecasts of futurologists, that the production companies that do not transfer their activities in the field of the Internet, will not become "e-companies", are doomed in the 21 st century - they have not come true. The consequences of the waves of recent financial crises have demonstrated that the preponderance of the production sphere over the sphere of circulation is a condition of national security and stability. The challenge for the modern global economy is not to build a digital economy as something unique that did not previously exist in the economy, on the contrary, it is the gradual creation of niches, as well as the digitalization of those areas of activity that are not considered to be digitized.

The analysis of strategic planning documents of various States devoted to the construction of the digital economy demonstrates a different understanding of the digital economy. On the one hand, everyone has different priorities - this is how it should be. In the documents, the role of the state is mainly reduced to the formation of conditions for the development of the digital market, as well as platforms for trade. Production issues are of secondary importance. We consider that the consideration of the digital economy through the prism of the sphere of circulation threatens the global economy with a round of inflating new financial bubbles. This is facilitated by the lack of theoretical and methodological basis for the study of modern trends, in particular trends in global digitalization.

Summing up, we note once again that the accuracy of the tasks in the state strategic documents determines the success of achieving the goals. The relevance of the exact definition of the category "digital economy" bases not only on the scientific ambitions of researchers in this field, but also on the strategic objectives. The accuracy of the interpretation is closely related to the need for a correct assessment of this economic phenomenon. Because of the uncertainty in the interpretation, the efforts of the state to support those activities that should be related to the digital economy become unproductive; the grown and transplanted interstate and national development institutions will be ineffective. As a result, an indistinct tracing of the phenomenon can threaten economies with losses of competitiveness and social stability.

\section{References}

1. McLuhan M. The Gutenberg Galaxy: The Making of Typographic Man. - Toronto: University of Toronto Press (1962).

2. Masuda Y. The International Society as Post-Industrial Society. World Future Society (1980).

3. Machlup F. The Production and Distribution of Knowledge in The United States. Princeton: Princeton University Press (1962)

4. Porat M. The Information Economy: Definition and Measurement / M. Porat. Washington, DC: United States Department of Commerce (1977).

5. Naisbitt J. Megatrends: Ten New Directions Transforming Our Lives / J.Naisbitt. New York: Warner Books (1982)

6. Mosco V. Pushbutton Fantasies: Critical Perspectives on Videotex and Information Technology. Norwood, NJ: Ablex (1982) 
7. Lyon D. The Information Society: Issues and Illusions / D. Lyon. - Cambridge: Polity (1988)

8. Dizard W. The Coming Information Age: An Overview of Technology, Economics, and Politics / W. Dizard. - New York : Longman (1989).

9. Stonier T. Information and the Internal Structure of the Universe: An Exploration into Information Physics. / T. Stonier. - Springer-Verlag (1990).

10. Castells M. The informational city: information technology, economic restructuring, and the urban-regional process / M. Castells. - Oxford, UK : Basil Blackwell (1991).

11. Gates B. The road ahead / B. Gates, N. Myhrvold, P. Rinearson. - New York: Viking (1995).

12. Negroponte N. Being Digital / N. Negroponte. - NY : Knopf, (1995).

13. Tapscott D. The Digital Economy: Promise and Peril in the Age of Networked Intelligence / D. Tapscott. - New York: McGraw-Hill (1997).

14. Kelly K. New Rules for the New Economy: 10 radical strategies for a connected world / K. Kelly. - New York: Viking (1998).

15. Schiller D. Digital Capitalism: Networking the Global Market System, Cambridge, MA: MIT Press (1999).

16. Cortada J.W. 21st Century Business: Managing and Working in the New Digital Economy / Cortada J.W. - Prentice-Hall International (2000).

17. Christensen J. The Industrial dynamics of the new digital economy / Christensen J. Maskell P. - Edward Elgar Publishing Ltd (2003).

18. Kehal H. Digital Economy: Imacts, Influences and Challenges /Kehal H., Singh V. IGI Global (2004).

19. Johansson B. The Emerging Digital Economy: Entrepreneurship, Clusters, and Policy (Advances in Spatial Science) / B. Johansson; C. Karlsson; R. Stough. - Berlin, Heidelberg: Springer (2006).

20. Illing G. Industrial Organization and the Digital Economy / Illing G, Peitz M. London: The MIT Press (2006).

21. Welfens P. Digital Economic Dynamics: Innovations, Networks and Regulations / Welfens P., Weske M. - Springer Beriin Heidelberg (2007).

22. Brousseau E. Internet and Digital Economics: Principles, Methods and Applications / Brousseau E., Curien N. - Cambridge; New York: Cambridge University Press (2007 ) .

23. Malecki E.J. The digital economy: Business organization, production processes and regional developments /Malecki E.J., B. Moriset. - NY: Routledge (2008).

24. Weber R. Classification of Services in the Digital Economy / Weber R.,Burri M. Staempfli and Springer (2012).

25. Schmidt E. The New Digital Age: Reshaping the Future of People, Nations and Business / E. Schmidt, J. Cohen. - New York: Alfred A. Knopf (2013).

26. Huws U. Labor in the Global Digital Economy: The Cybertariat Comes of Age / U. Huws. - New York: Monthly Review Press (2014).

27. Holroyd C. The Global Digital Economy: A Comparative Policy Analysis / Holroyd C. Coates K.S. - NY: Cambria Press (2015).

28. Boccia F. The challenge of the digital economy: Markets, taxation and appropriate economic models / F. Boccia, R. Leonardi. - Palgrave Macmillan (2016). 
29. Elder-Vass D. Profit and Gift in the Digital Economy / Elder-Vass D. - Cambridge; New York: Cambridge University Press ( 2016).

30. U.S. Chamber of commerce. Made in China 2025: global ambitions built on local protections.

31. https://www.uschamber.com/sites/default/files/final_made_in_china_2025_report_full. pdf

32. http://english.gov.cn/2016special/internetplus/

33. A Next Generation Artificial Intelligence Development Plan, (2017). https://chinacopyrightandmedia.wordpress.com/2017/07/20/a-next-generationartificial-intelligence-development-plan/

34. Federal Ministry for Economic Affairs and Energy, (2017). Digital Strategy 2025

35. https://www.de.digital/DIGITAL/Redaktion/EN/Publikation/digital-strategy-2025.html

36. European Commission, (2017). Digital Transformation Monitor. Germany: Industrie 4.0.

37. https://ec.europa.eu/growth/toolsdatabases/dem/monitor/sites/default/files/DTM_Industrie\%204.0.pdf

38. Government of France, (2016). NOUVELLE FRANCE INDUSTRIELLE. Construirel'industriefrançaise du future.

39. https://www.entreprises.gouv.fr/files/files/directions_services/politique-etenjeux/nouvelle-france-industrielle/industrie-du-futur-dp-2016-05-23.pdf

40. Department for Digital, Culture, Media \& Sport, (2017). UK Digital Strategy.

41. https://www.gov.uk/government/publications/uk-digital-strategy/uk-digital-strategy

42. HM Government, (2013). Information Economy Strategy. Industrial Strategy: government and industry in partnership.

43. https://assets.publishing.service.gov.uk/government/uploads/system/uploads/attachmen t_data/file/206944/13-901-information-economy-strategy.pdf

44. Australian Government, (2010). National Digital Economy Strategy. Leveraging the National Broadband Network to drive Australia's Digital Productivity. http://rdanwq.org.au/files/National_Digital_Economy_Strategy.pdf

45. https://plattformindustrie40.at/

46. Program the Digital economy of the Russian Federation. The decree of the RF Government of July 28.2017. No. 1632-the Moskva river. 13.http://static.government.ru/media/files/9gFM4FHj4PsB79I5v7yLVuPgu4bvR7M0.p df

47. Ministry of Internal Affairs and Communication, Japan. Smart Japan ICT Strategy, (2014). http://www.soumu.go.jp/main_content/000301884.pdf

48. 1https://ec.europa.eu/digital-single-market/

49. Government offices of Sweden. Ministry Enterprise and innovation. Smart industry - a strategy for new industrialization for Sweden. https://www.government.se/contentassets/3be3b6421c034b038dae4a7ad75f2f54/nist_s tatsformat_160420_eng_webb.pdf

50. European Commission, (2017). Digital Transformation Monitor. The Netherlands: Smart Industry.

51. https://ec.europa.eu/growth/toolsdatabases/dem/monitor/sites/default/files/DTM_Smart\%20Industry\%20v1.pdf 
52. OUP 2017. Digital Economy, Oxford Dictionary, Oxford University Press, Oxford, UK. https://en.oxforddictionaries.com/definition/digital_economy

53. G20 DETF, (2016). G20 Digital Economy Development and Cooperation Initiative, G20 Digital Economy Task Force. http://www.g20.utoronto.ca/2016/g20-digitaleconomy-development-and-cooperation.pdf

54. EC, (2013). Expert Group on Taxation of the Digital Economy, European Commission, Brussels.

55. http://ec.europa.eu/taxation_customs/sites/taxation/files/resources/documents/taxation/ gen_info/good_governance_matters/digital/general_issues.pdf

56. OECD, (2016). Measuring GDP in a Digitalised Economy, OECD, Paris. www.oecd.org/dev/Measuring-GDP-in-a-digitalised-economy.pdf

57. DBCDE, (2013). Advancing Australia as a Digital Economy: An Update to the National Digital Economy Strategy, Department of Broadband, Communications and the Digital Economy, Canberra. http://apo.org.au/node/34523

58. Mesenbourg, T.L., (2001). Measuring the Digital Economy, US Bureau of the Census, uitland, MD. https://www.census.gov/content/dam/Census/library/workingpapers/2001/econ/umdigital.pdf

59. Program the Digital economy of the Russian Federation. The decree of the RF Government of July 28. (2017). No. 1632-the Moskvariver. 13. 